\title{
Multi-level Negotiations on Digital Trade Policy ${ }^{2}$
}

The 2018 session of the WTO Public Forum was organized by the HSE jointly with the University of Carleton (Canada), the Center for the Development of Trade Policy of the Republic of Kazakhstan and experts from Belarus. In particular, the discussion focused on factors that, in the conditions of rapid development of digital technologies, could lead to discrimination related to exchange of information and access to digital infrastructure, which are still beyond the scope of multilateral agreements. This article concludes on the main issues on the digital trade policy and socio-economic development. Discussion of these points at the WTO Public Forum has brought practical understanding of the application of the rules of trade within the digital economy.

Key words: WTO, trade agreements, inclusivity, digital trade, socio-economic development, Canada, Africa.

\section{JEL F13}

\section{Introduction}

The world transformation which is going on with the help of global institutions such as the WTO, which has placed its focus on digital trade within operating with emerging technologies, has become a complex system of economic and trade relationships and negotiations taking place at different levels. The movement of factors of production has progressed to an extent where new factors, such as data and information, are playing a major role. That enables the countries to create an environment in trade relations, where digital platform becomes the main ground for trading. It interacts with other elements of digital transaction chains (Fig. 1).

Digital technologies not only bring a great number of opportunities, but also specific challenges that require the consideration of governments and the international community. That is why the WTO has addressed this issue from the perspective of growing demand on digital trade on goods and services.

1 Nathoo Rosemina - Senior Trade Law Advisor, Centre for Trade Policy and Law (CTPL), Carleton University/University of Ottawa, Canada. E-mail: <rznworld@gmail.com>. 


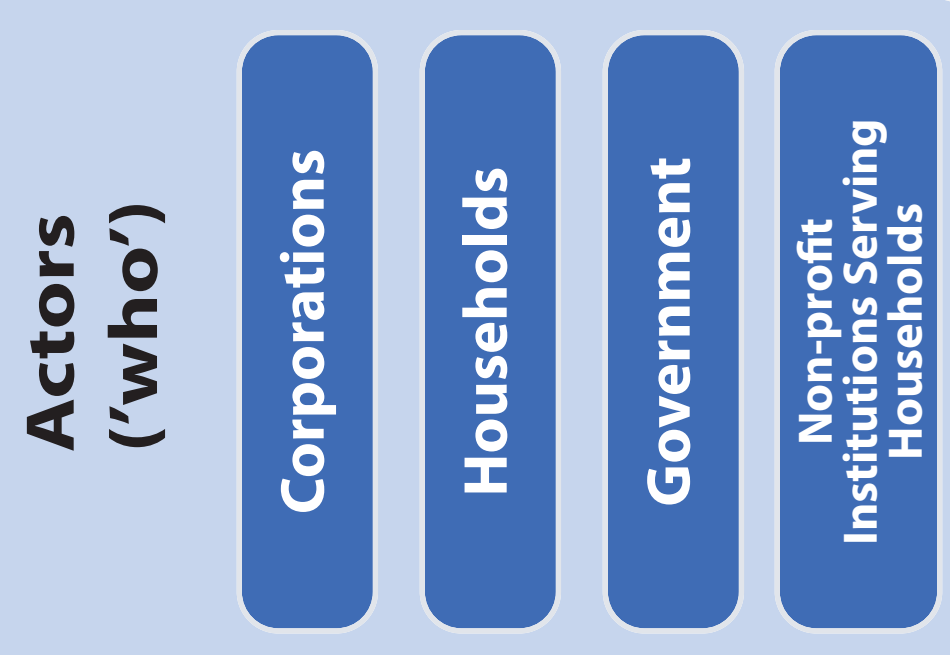

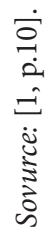
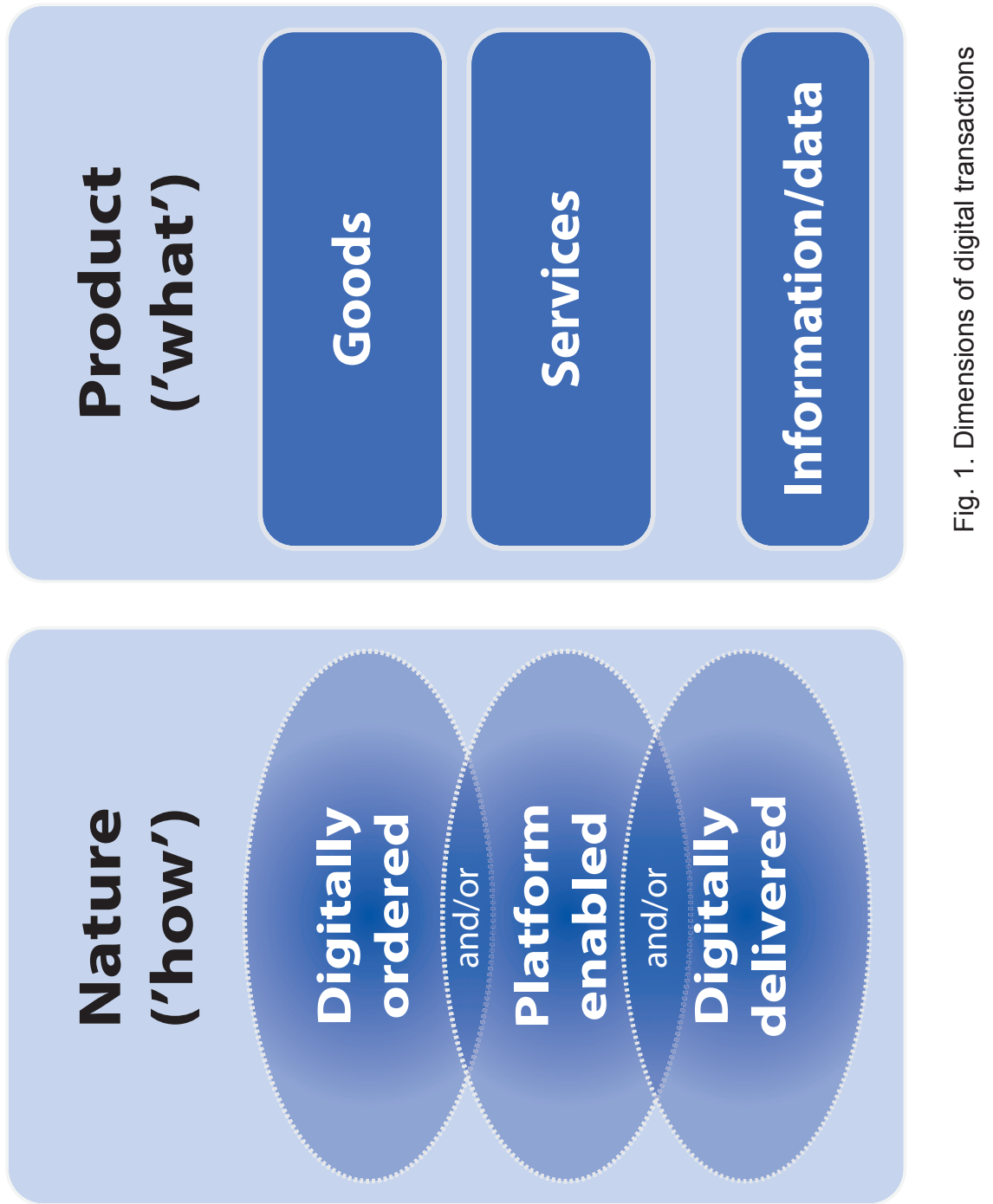
The practical steps which have been mentioned above determine how trade rules as a tool for progress and socio-economic development may work. Those practical steps, which will be discussed later, were shown based on examples of Canada and Africa.

\section{The case of Canada}

Canada is a progressive country with a big number of ways to evolve its trade relationships. The current implications for Canada are based on Canada's Progressive Trade Agenda (PTA), which has a direct linkage to the development of digital economy. The well-known problems of incorporating the digital trade into the international trade relations have been overlooked and proposed a practical solution throughout the WTO 2018 Global Forum.

Canada Progressive Trade Agenda has several key indicators which the whole trade system in the country is based on:

- achieving a fairer sharing of the gains from trade, with a particular emphasis on jobs for the middle class [2, p. 23].

- This implies that the country's main aim is to provide as many jobs for the middleclass workers as the system can in order to ensure the high standards of living.

- $\quad$ specific focus on women, indigenous peoples, youth, and small and mediumsized enterprises (SMEs);

- specific reference to labour and the environment;

- safeguarding the government's right to regulate in the public interest;

- procedural reforms to achieve greater transparency and participation of civil society in negotiations; and

- communications to sell the benefits of trade and investment.

On the whole, the country's case provides a clear idea of what the trade agenda of a developed country looks like. These indicators have to be reached at different levels to be successful, so the government seeks to establish them on every part of the trade relation system. The steps have to be taken to deal with the problems of digital trade. The problems, that appear to be solved on the way towards a successful system, include several issues, mentioned on the session of the Global Forum. Those include:

- the easiness of coping products and services has emerged, with the creation of new digital infrastructure

- the new problems with intellectual property

- the dependence of the trade, in order to get access to the market, on the business environment and internal regulations

- the differences between the socio-economic development among the developed and developing countries.

These ideas are challenging, thus the intervention strategies have to be made at the multilateral, plurilateral and as well as domestic levels. 
Specifically, on the basis of the purpose of the WTO Global Forum, the linkages and connections between the Canada's agenda and the digital economy have been provided. The key priority that is the most essential for digital economy development is inclusive trade and inclusive growth. Those concepts have been further qualified, reinforced and endorsed at the multilateral level by the WTO, the G20, and the World Economic Forum. However, specifically, the definition that mostly describes the aforementioned technique is as follows: "Inclusive trade and growth is building a system where the benefits are shared more widely by entrepreneurs, MSMEs, women and marginalized groups in all economies."

The progressive trade approach examines the ways to address the barriers posed by the digital movement that limits the opportunities for women, indigenous people, MSMEs, and, on the whole, the international trade. For example, overlooking the case of the small and medium sized businesses, the idea that is pursued by the Canada's Trade Agenda is to improve the policy environment for innovation and promote small micro enterprises growth through innovation, including strengthening digital competitiveness in order to access the opportunities of the Internet and the digital economy.

As mentioned, Canada's inclusive growth is a key socio-economic development priority. Canada is committed to pursuing all of the progressive three principles in its bilateral, multilateral and regional trade negotiations.

Another example can be shown on the basis of NAFTA. Prior to the recent conclusion of the negotiations on NAFTA 2.0 (USMCA) the session came to the agreement that highlighted the necessity to include a digital trade chapter on purpose of the ability of a separate protocol agreement to be able to deal with intellectual property and digital rights management.

In the EU-Canada Comprehensive Economic and Trade Agreement (CETA) there is an article that determines the fact where the potential of e-commerce is seen as a social economic development tool. Furthermore, the agreement sets a pathway for collaboration between Canada and the European Union to approach the challenges and problems that arise in the future with respect to the Internet and digitalization.

Canada's recent attempts that were leaked in to the press were devoted to Canada's most recent draught blueprint to reform the WTO in terms of modernization and enhancement of the WTO rules; the draught includes a section to address the 21 st century trade practices, involving digital trade. That brings a potential on what to expect from the implementation of digital trading in the future.

\section{The case of Africa}

There are experiments that have been going on to assure that the negotiations for the establishment of trade areas around the world ranging from developed countries to the least developing ones to create a truly worldwide system of trade. As 
an example, the current situation in Africa where there are attempts to build a free trade area which have successfully been implemented via an agreement on goods and services trade.

In terms of Africa's transformation industrialization agenda, as it has been mentioned, African continental free trade area was successfully established and signed by its parties in 2018. There will be a phase two for the further liberalization which is supposed to involve negotiations to draught a separate digital commerce protocol.

There are specific reasonings behind that. The main cause of that is that digital trade is rapidly growing in Africa, so there have to be significant changes for the way African countries trade and industrialize, and that puts digital trade in the center of attention. Nevertheless, Africa in this account comes forward to progressive trade and inclusivity and strives to promote human rights by closing the digital divides, promoting more Internet access infrastructure and development through job creation [3, p. 43]. Price indexes should also be take into account (see Fig. 1). However, there are risks and threats based on digital trade and its advancement.

This means that different countries have different capacities to be able to be in a place to take advantage of those benefits. The biggest constraints for Africa are based on poverty and lack of education and skills. Lack of capital in education of people appear a disadvantage in African countries to reach the rewards of e-commerce. In terms of human rights digitalization, it is essentially important to pay attention to ownership and identity as fundamental human rights.

Overlooking at digital trade as a tool for economic development or socio-economic development [4, p. 19]. The objective lies in that the digital economy should be treated as an equalizer that fits utilities bridging the gap between the rural and urban areas to ensure that girls and women equally have access to the international system.

\section{Conclusion}

To sum up, e-commerce and digital trade will have a great impact at all levels domestic, regional and international; this requires complementary strategies at the multilateral, plurilateral and bilateral levels. Canada attempts to advance its progressive trade agenda through active trade negotiations to conclude free trade agreements.

Ultimately, comprehensive consistent and systematic approach at the WTO level as well as the plurilateral and bilateral levels will be needed to handle the speed and intensity with which this digital world is growing, and the challenges that arise. All these should have a positive impact on socio-economic development. 


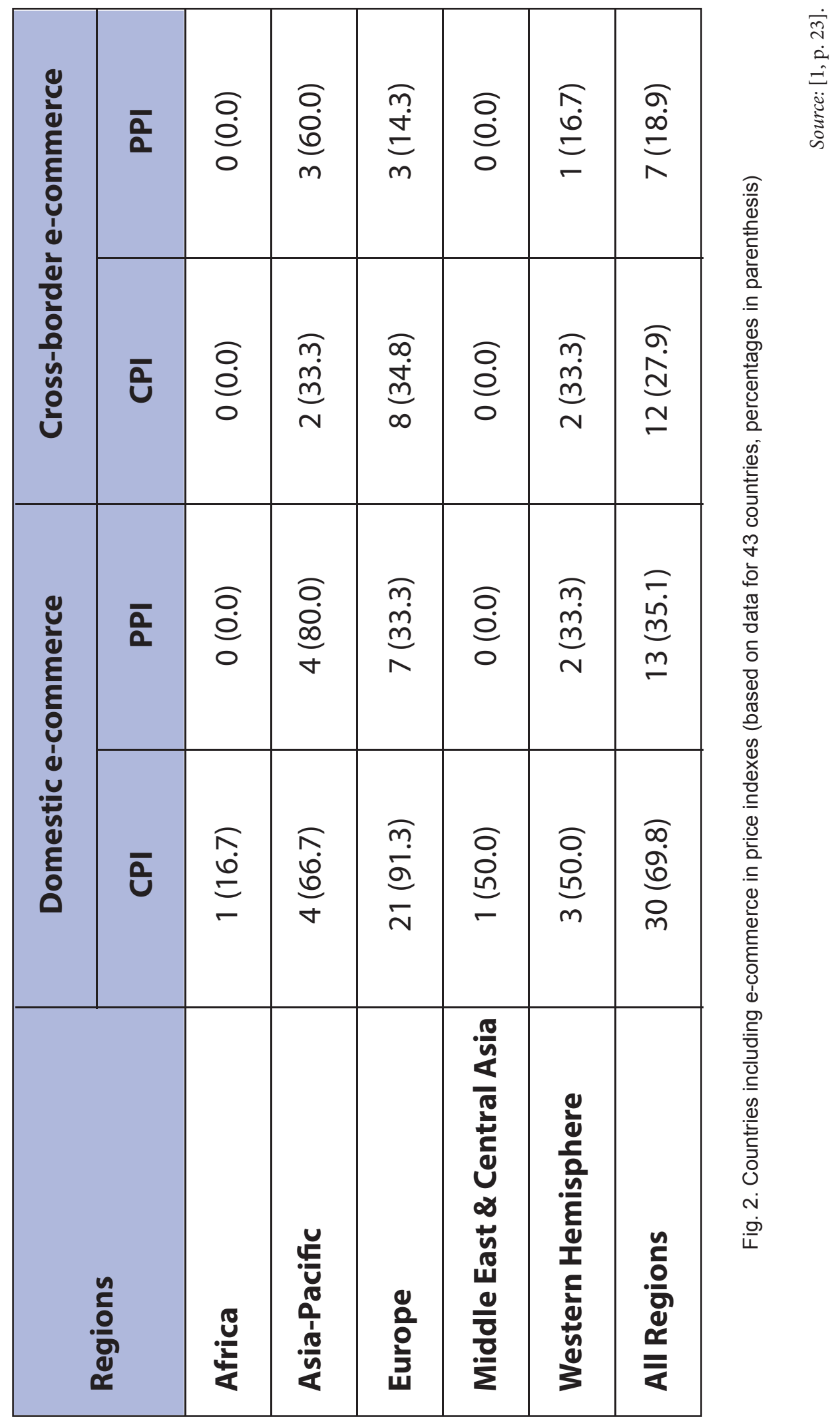




\section{References}

[1] IMF (2018) Measuring the digital economy. URL: <https://www.imf.org/en/ Publications/Policy-Papers/Issues/2018/04/03/022818-measuring-the-digital-economy $>$.

[2] Berger T., Frey C.B. (2016) Digitalisation, deindustrialisation and the future of work. OECD Social, Employment and Migration Working Papers, No. 193. Paris.

[3] Marien I., Prodnik J. A. (2014). Digital inclusion and user (dis)empowerment: A critical perspective // The Journal of Policy, Regulation and Strategy for Telecommunications,. No. 16(6). P. 35-47.

[4] Einav L., Levin J. (2014). Economics in the Age of Big Data. Science 346 (6210). 
Haтy P. $^{1}$

\section{Обсуждение циффровой торговой политики}

\section{на различных уровнях торговьх}

переговоров ${ }^{2}$

Сессия по тематике данной статьи была организована на Общественном форуме ВТО 2018 г. Высшей школой экономики (РФ) совместно с Карлтонским университетом (Канада), Центром развития торговой политики (Казахстан) и экспертами из Республики Беларусь. Фокусом дискуссии стали факторы, которые в условиях быстрого развития цифровых технологий могут привести к дискриминации в отношении обмена информацией и доступа к цифровой инфраструктуре, но находятся за пределами многостороннего регулирования. В статье делаются выводы об основных проблемах цифровой торговой политики и социально-экономического развития. Обсуждение этих вопросов на Общественном форуме ВТО поспособствовала повышению осведомленности участников по поводу применения правил торговли в условиях цифровой экономики.

Ключевые слова: ВТО, торговые соглашения, цифровая торговля, социально-экономическое развитие, Канада, Африка.

JEL F13

1 Роземина Нату - Стариий советник по праву международной торговли, Центр торговой политики и права, Университет Оттавы, Канада. E-таil: < world@gmail.com>. 